УДК 551.4 .04

\title{
РАСЧЕТ УСТОЙЧИВОСТИ СКЛОНОВ НА УЧАСТКАХ СТРОИТЕЛЬСТВА ОБЪЕКТОВ СПОРТИВНО-ТУРИСТИЧЕСКОГО КОМПЛЕКСА «ГОРНЫЙ ВОЗДУХ» (ГОРА БОЛЬШЕВИК, Г. ЮЖНО-САХАЛИНСК)
}

\author{
Ильин Владимир Вениаминович', \\ vladimirilyin7@gmail.com \\ Сахаров Валерий Александрович', \\ sakhsakh@yandex.ru \\ 1 Сахалинский государственный университет, \\ Россия, 693000, г. Южно-Сахалинск, ул. Ленина, 290.
}

\begin{abstract}
Актуальность исследования обусловлена необходимостью обеспечения безопасности эксплуатации объектов СТК «Горный воздух». На Склоновой части СТК опасность могут представлять оползневые процессы. Для оценки динамики развития оползневых процессов в местах массового скопления людей при эксплуатации СТК выполнена первая стадия специализированного мониторинга.

Цель: изучить динамику оползневых процессов и выполнить оценку устойчивости склонов в местах скопления большого количества отдыхающих и спортсменов для целей их безопасного пребывания.

Объекты: Северный, Южный и Западный склоны горы Большевик; грунты, слагающие верхнюю часть литосферы до глубины 10 м; подземные воды.

Методы: выполнение профильных исследований в крест простирания склона - маршрутные рекогносцировочные обследования, проходка шурфов до двух метров глубиной (полное прохождение делювиальных отложений и вскрытие элювиальных пород), отбор проб ненарушенной структуры с интервалом 0,2-0,3 м, геофизические исследования методом георадиолокационного просвечивания с использованием мобильной георадарной установки ОКО-2, лабораторное тестирование отобранных образцов грунта. Грунтовые воды в процессе исследований не встречены.

Результаты. По данным исследований в ноябре-декабре 2017 Г. на трех участках СТК «Горный воздух» - Северный склон, Южный и Западный склоны - выделены репрезентативные участки на склонах, выполнено уточнение инженерно-геологического разреза перечисленных склонов, в частности - положение границы «делювий-элювий», произведен расчет инженерно-геологических элементов и расчеты коэффициентов устойчивости склонов в пределах изученных участков по методике касательных сил для прислоненного откоса при отсутствии грунтовых вод.
\end{abstract}

\section{Ключевые слова:}

Склон, склоновые процессы, оползневые процессы, делювиальные отложения, элювий, объемный вес грунта, угол внутреннего трения, уклон поверхности скольжения, грунтовые воды, сейсмичность территории.

\section{Введение}

Развитие Спортивно-туристического комплекса (СТК) «Горный воздух» для Сахалинской области и Дальнего Востока РФ имеет приоритетное значение. Ежедневно комплекс принимает сотни и тысячи спортсменов и отдыхающих, как в зимний, так и в летний периоды. Соответственно, безопасность эксплуатации объекта и безопасность пребывающих там людей выходит на первый план [1-3]. В этой связи администрация СТК «Горный воздух» начала реализацию программы мониторинга по изучению развития склоновых процессов в пределах территории комплекса.

\section{Исходные данные}

В качестве исходных данных были изучены сведения о климате, гидрографической сети, рельефе, геоморфологии, особенностях геологического строения, гидрогеологических условиях, геологических и инженерно-геологических процессах, физико-механических свойствах грунтов, техногенных воздействиях на окружающую среду, отраженные в технических отчетах по результатам инженерных изысканий на территории СТК. Так- же было оценено современное состояние изученности склоновых процессовв научно-исследовательской литературе [4-16]. На основании собранных материалов был определен состав, объемы и методика исследовательских работ.

Исследования были выполнены для трех участков (рис. 1) канатно-кресельных и гондольных трасс - Северный склон (рис. 2), Трасса Юг (рис. 3) и Трасса Запад (рис. 4) (результаты получены в рамках выполнения государственного задания Минобрнауки РФ: 5.9560.2017/8.9). На каждом участке был отработан профиль протяженностью 210-320 м, с проходкой шести шурфов глубиной до двух метров, отбором проб грунта с интервалом $0,2-0,3$ м и георадиолокационным просвечиванием георадарной установкой ОКО-2 до глубины 10-12 м. Для отобранных образцов грунта были выполнены физические тесты в грунтовой лаборатории СахГУ. Механические характеристики выделенных ИГЭ были приняты по результатам ранее выполненных работ, показатели удельного сцепления для ИГЭ-3 оценены по справочным данным, так как лабораторные значения для выветрелых сланцев выглядят несколько завышенными (для сравнения - 0,015 и 0,25 МПа). 


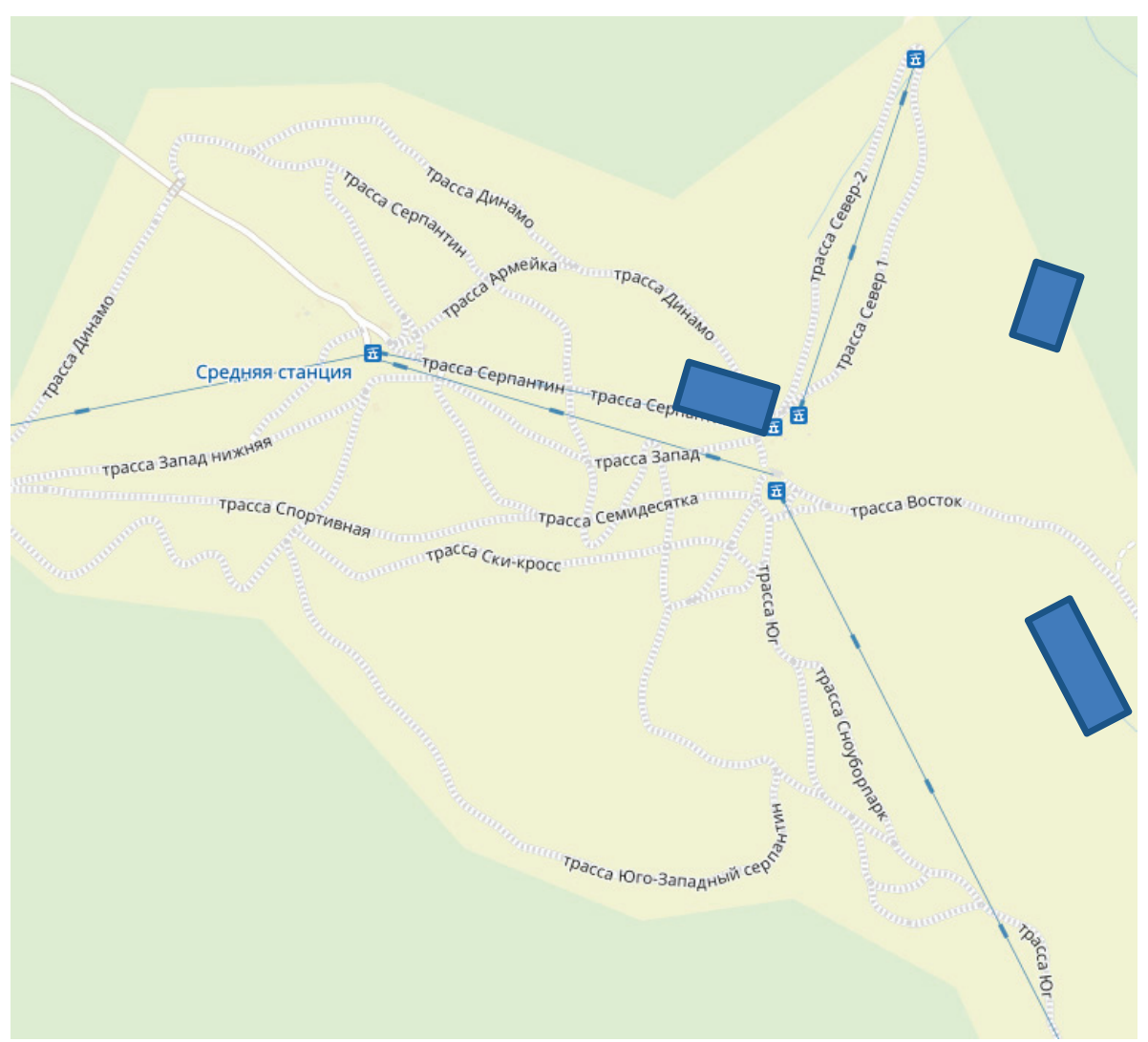

Pис. 1. Схема расположения участков мониторинговых исследований

Fig. 1. Scheme of location of monitoring sites

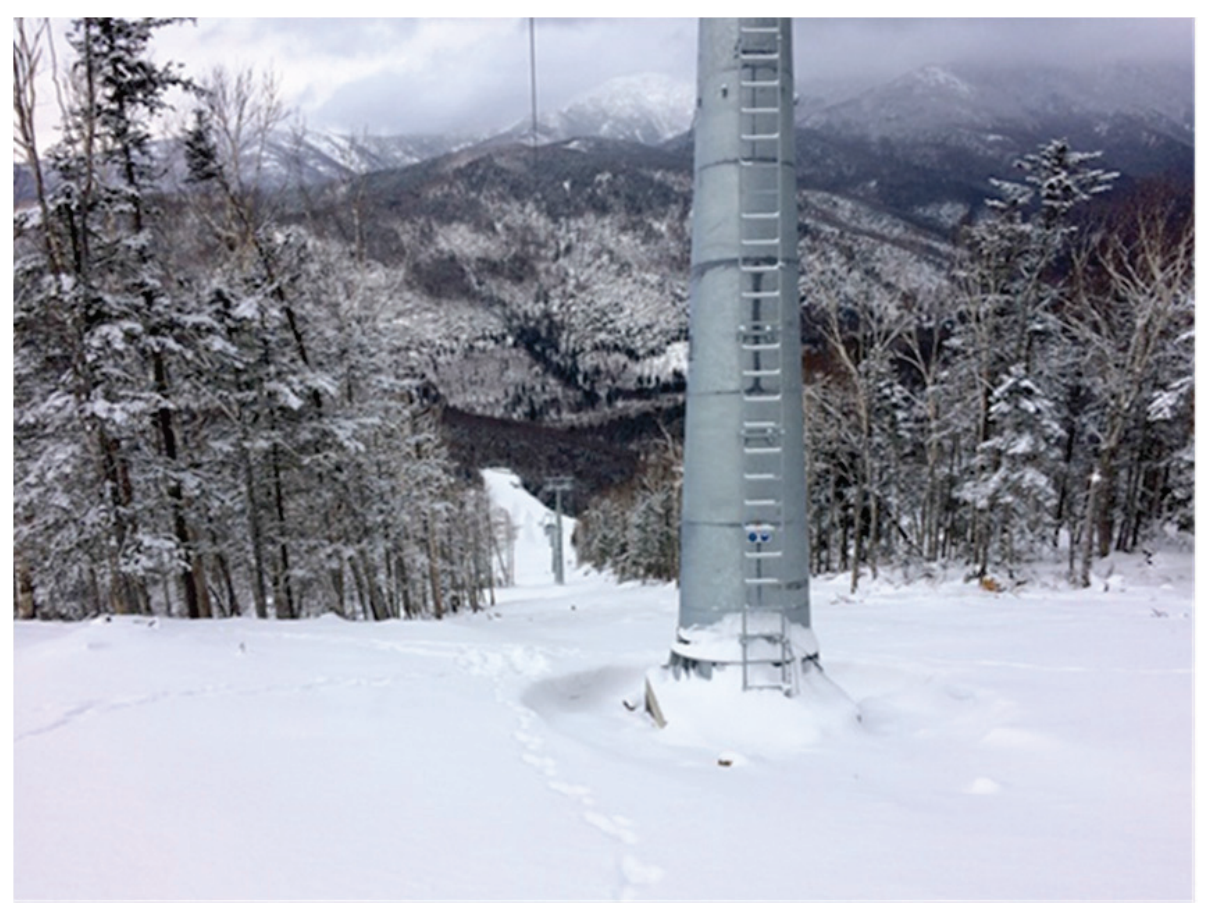

Рис. 2. Канатно-кресельная трасса «Северный склон»

Fig. 2. Cable-chairlift «Severny sklon» 


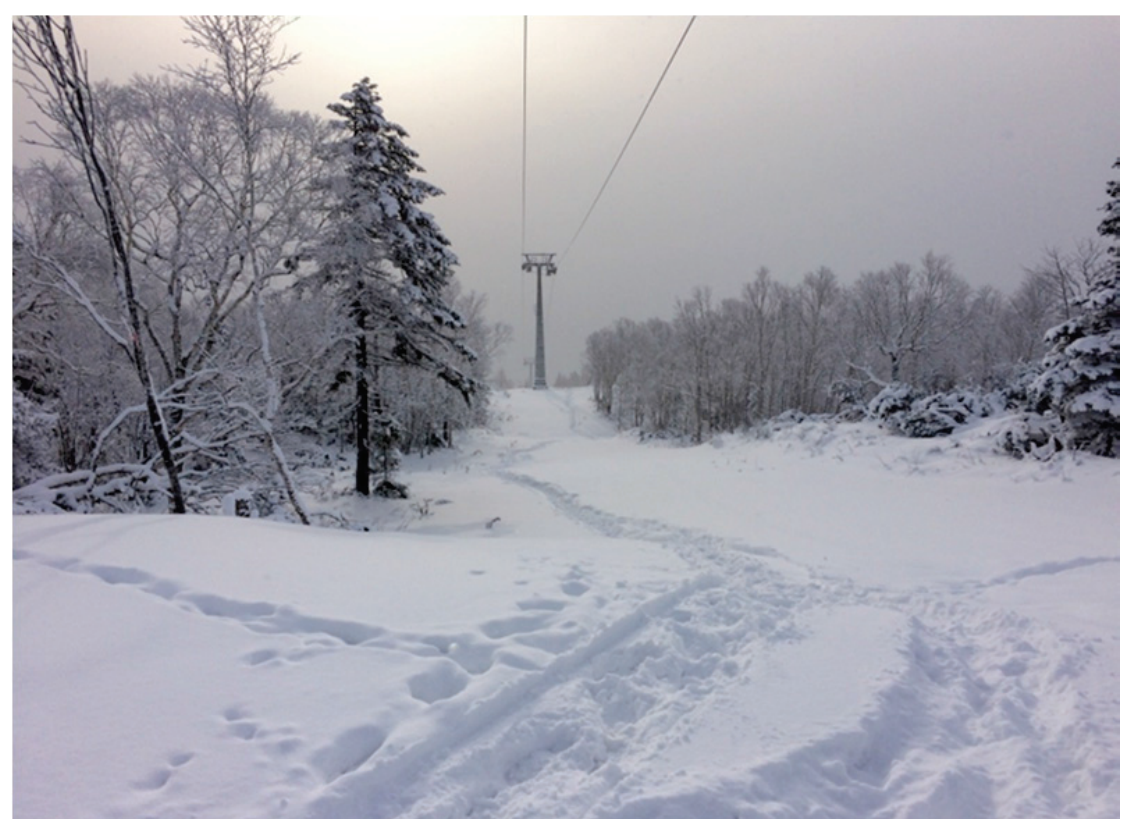

Рис. 3. Канатно-кресельная трасса «Юz»

Fig. 3. Cable-chairlift «Yug»

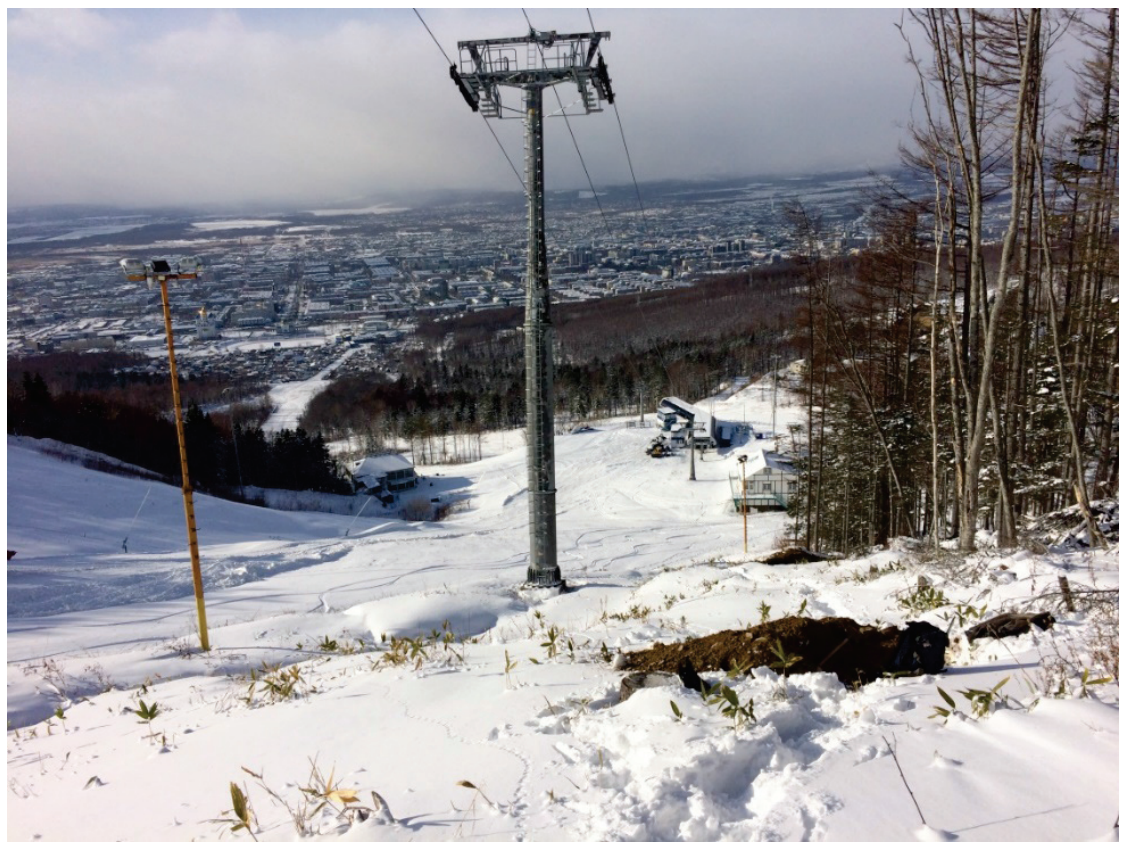

Pис. 4. Канатно-гондольная трасса «Запад»

Fig. 4. Cable-gondola route «Zapad»

Климат. Для Южно-Сахалинской климатической зоны, как и для всего острова Сахалин, характерна сезонная смена воздушных течений, возникающих под влиянием термических контрастов между материком и океаном, а также вызываемая изменением в местоположении тихоокеанского антициклона и тропосферных фронтов (полярного и арктического) [17]. С октября по март в районе дальневосточных морей господствует зимний тип циркуляции, формирующийся осенью, на фоне нагретого за лето океана и быстро охлаждающегося материка, а весной - наоборот. Летом характерно активное развитие циклонической деятельности над Азиатским континентом (дальневосточная депрессия над бассейном Амура) и антициклогенез (северо-тихоокеанский и охотский антициклоны) над Тихим океаном и дальневосточными морями. Взаимодействие летней дальневосточной депрессии с северо-тихоокеанским и охотским антициклонами обусловливает интенсивный перенос в летнем муссоне теплых и влажных масс воздуха с океана на материк. 
Геолорфология и рельеф. В геоморфологическом отношении территория исследований приурочена к северо-западному отрогу Сусунайского хребта, который является складчато-горстовой структурой сложного строения [18]. Западные склоны Сусунайского хребта плавно переходят в Сусунайскую межгорную впадину (Сусунайскую депрессию). Абсолютные отметки поверхности земли в пределах исследуемого участка изменяются от 100,0 до 599,4 м БС (вершина горы Большевик). Углы наклона склона изменяются в значительной степени: нижняя половина склона характеризуется углами наклона от 5-7 до 22-25 градусов, а на верхнем участке площадки исследований крутизна склона превышает 30 градусов.

Гидрология. Рассматриваемый район, как и вся территория Сахалина, относятся к зоне избыточного увлажнения [17]. Для нее характерны два сезона с максимальным стоком - весеннее половодье и дождевые паводки, и два сезона с минимальным стоком - летняя и зимняя межень. По данным ФГБУ «Сахалинское УГМС» установлено, что в рассматриваемом районе максимальные расходы воды и соответствующие им уровни дождевых паводков значительно превышают уровни и расходы весеннего половодья. Питание рек и ручьёв смешанное -снеговое, дождевое, грунтовое. В маловодные периоды устойчивое питание водотоков осуществляется преимущественно за счет разгрузки грунтовых вод. В местах сокращения мощности или полного выклинивания грунтового водоносного горизонта формируются родники нисходящего типа. Реки и ручьи рассматриваемого района относятся к типу водотоков с весенним половодьем и летне-осенними дождевыми паводками. Доля стока талых вод в годовом объёме составляет 50-60 \% . Грунтовое питание устойчивое [19]. Его доля составляет 10-15\% общего стока.

Геологическое строение. В геологическом строении исследуемой территории принимает участие комплекс метаморфических пород красноярковской свиты верхнего отдела меловой системы $\left(\mathrm{K}_{2} \mathrm{kr}\right)[18$, 20], представленной зеленокаменными породами, хлорит-эпидот-кварцевыми сланцами, которые образуют сложную складчатую структуру с узкими линейно вытянутыми складками с пологими углами наклона крыльев $\left(25-50^{\circ}\right)$ восточного простирания. Хлорит-эпидот-кварцевые сланцы красноярковской свиты $\left(\mathrm{K}_{2} \mathrm{kr}\right)$ практически повсеместно перекрыты чехлом отложений четвертичной системы (Q).

Отложения неогеновой системы распространены локально в нижней части исследуемого участка и представлены алевролитами (туфогенными) аракайской свиты неогена $\left(\mathrm{N}_{1} \mathrm{ar}\right)$.

Четвертичные отложения широко распространены и залегают непосредственно на дневной поверхности, имеют мощность от 0,3 до 25 м. Представлены разнообразными генетическими типами, среди которых наиболее широко развиты делювиальные, коллювиальные, элювиальные и техногенные образования.
Тектоника. В тектоническом отношении исследуемая территория расположена в районе дифференцированных блоковых движений (Западно-Сусунайская шовная зона течения и метаморфизма), где выделяется сусунайский взброс - региональное разрывное нарушение, которое прослеживается по западному борту сусунайской депрессии в меридиональном направлении и ограничивает с востока поле распространения верхнемеловых пород [20]. Разлом сопровождается зоной брекчевания шириной около 0,5 км, оперяющими разрывами (более молодыми, крутопадающими сбросами и сбросо-надвигами) и широкой полосой $(2-3$ км) интенсивных пликативных деформаций пород, в пределах которой породы падают под крутыми углами, а иногда и опрокинуты. Амплитуда смещения по разлому достигает 3-4 км. Плоскость смещения падает на запад под углом 50-60. Разрывное нарушение имеет длительную историю развития с неоднократными обновлениями. Омолаживание взброса происходило и в четвертичное время. Сейсмичность территории по данным детального сейсмического районирования оценивается в 8 баллов [21].

Физико-механические свойства грунтов. В результате анализа показателей физических свойств грунтов, определенных лабораторными методами, их пространственной изменчивости, а также данных о геолого-литологическом строении, на вскрытую глубину до 2 м выделено 4 инженерногеологических элемента (ИГЭ) (рис. 5, 6). Пятый инженерно-геологический элемент выделен по результатам геофизических исследований и результатам предыдущих изысканий.

Вскрытые грунты представлены связными грунтами четвертичного возраста и элювием метаморфических сланцев, дезинтегрированных до размеров глыб и щебня с песчано-глинистым заполнителем.

Грунтовые воды не встречены ни в одной горной выработке.

ИГЭ-1 - почвенно-растительный слой, мощность $-0,15$ м.

ИГЭ-2 - суглинок делювиальный, коричневый, тугопластичный, легкий, с дресвой и щебнем до $30 \%$. Развит по всему разрезу, мощность слоя изменяется от 0,35 до 0,75 м. Залегает в интервале глубин от 0,15 до $0,9 \mathrm{M.}$

ИГЭ-3 - щебенистый грунт, делювиальный, с дресвой и супесчаным заполнителем твердой консистенции (некоторые пробы характеризуются по показателю текучести как пластичные, но, в основном твердые). Щебень малопрочный. Развит по всему разрезу, мощность слоя изменяется от 0,3 до 0,7 м. Залегает в интервале глубин от 0,5 до 1,4 м.

ИГЭ-4 - элювиальный грунт - специфический грунт - метаморфический сланец, дезинтегрированный до размеров глыб и щебня с песчано-глинистым заполнителем. Мощность элювия по данным геофизических исследований составляет 0,5-1,0 м. Кровля элемента залегает в интервале глубин от 0,8 до 1,4 м. 
ИГЭ-5 - сланец скальный, выветрелый, средней прочности, трещиноватый, размягчается в воде. Подстилает элювиальный грунт и выделен по результатам геофизических исследований. Кровля элемента залегает в интервале глубин от 1,5 до 2,2 м. Мощность - более двух метров.

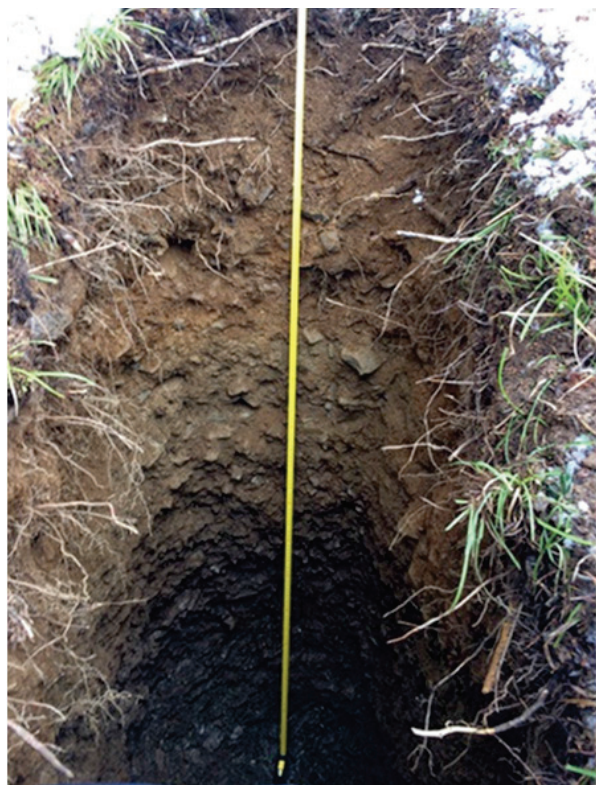

Pис.5. Внешний вид грунтов от первого до четвертого ИГЭ (шурф № 3, глубина 2 м)

Fig. 5. Appearance of soils from the first to fourth layer (pit № 3, depth $2 \mathrm{~m}$ )

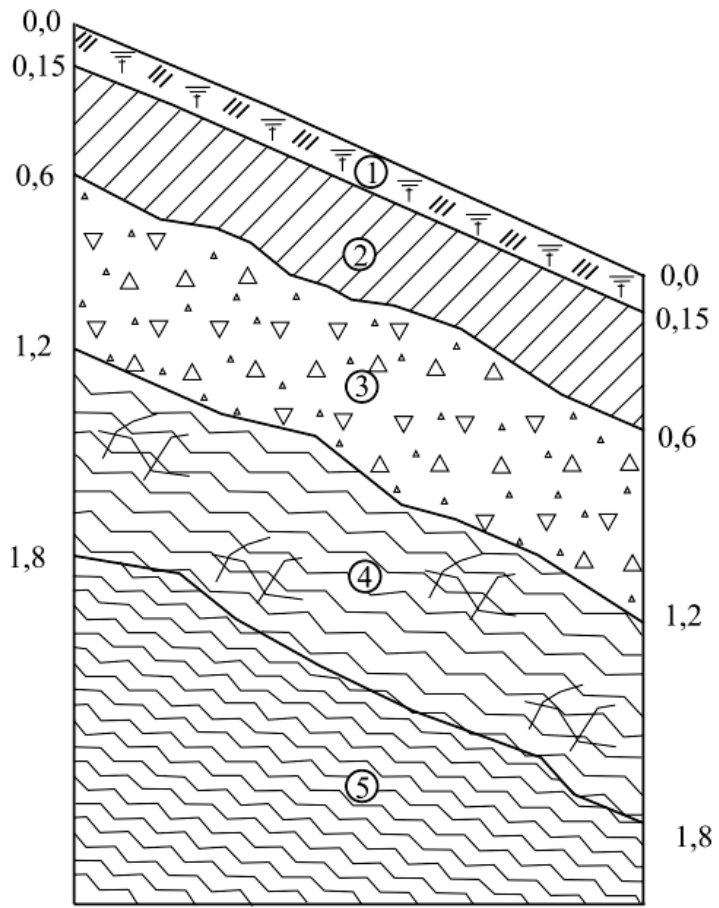

Puc. 6. Схематичный инженерно-геологический разрез с отраже нием истинного угла наклона залегания инженерно-геологических элементов и их мощности

Fig. 6. Schematic engineering-geological section with reflection of the true angle of incidence of engineering geological elements and their capacity
Специфические грунты. К специфическим грунтам на исследуемой территории относятся элювиальные грунты (ИГЭ-4) - метаморфический сланец, дезинтегрированный до размеров глыб и щебня с песчано-глинистым заполнителем. Мощность элювия по данным геофизических исследований составляет $0,5-1,0$ м. Кровля грунтов залегает в интервале глубин от 1,1 до 1,4 м.

Грунт подвержен физико-химическому выветриванию, обусловленному взаимодействию горных пород с водой.

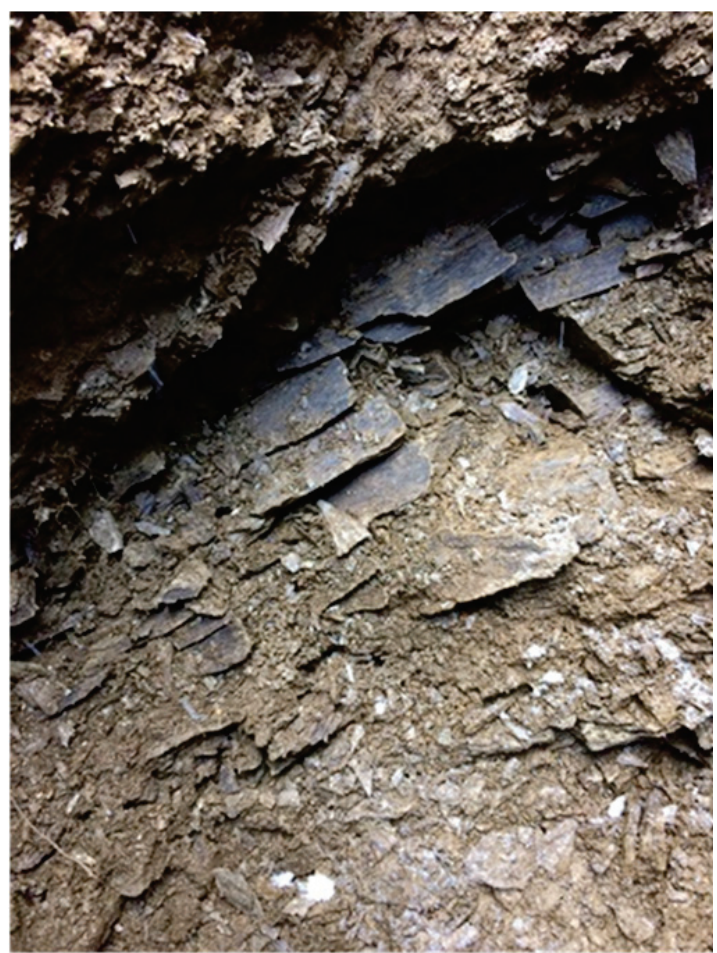

Рис. 7. Залегание грунтов на границе «делювий-элювий»

Fig. 7. Occurrence of soils at the deluvium-eluvium boundary

Элювиальные грунты вскрыты во всех шурфах.

Породы имеют хорошо выраженную слоистость и трещиноватость, при вскрытии сохраняют устойчивое положение в стенке выработки, но легко разбиваются при ударе кайлом на мелкие частицы, включая пылевато-песчаные.

В этой связи следует отметить, что в период изысканий уделено мало внимания изучению элювиальных грунтов. Более того, они чаще всего объединены в «делювиально-элювиальные», что недопустимо по требованию руководящих документов [22]. Это связано с тем, что при прохождении скважин границу делювиальных и элювиальных отложений отследить весьма сложно, практически невозможно, так как элювиальные отложения легко разбиваются буровым инструментом и при извлечении полностью теряют природную структуру и текстуру и, соответственно, принимаются за щебень и дресву с песчано-глинистым заполнителем. Глубина залегания элювиальных грунтов по ранее выполненным работам оценена в пределах 5-7 м. 
Вместе с тем граница «делювий-элювий» очень хорошо выражена и легко прослеживается при вскрытии шурфами (рис. 7). На фотографии эта граница так заметна, что не требует дополнительных усилий для ее выделения. Она прослеживается на глубине 1,1-1,4 м. Также наблюдается единое структурно-текстурное строение горных пород в массиве геологической структуры. И это строение демонстрирует хорошую связь элювиальных грунтов с материнским основанием.

По геофизическим данным подошва элювиальных грунтов имеет невыдержанный характер - на отдельных участках она находится ближе к делювиальным отложениям, а на других - несколько отдаляется от них, увеличивая мощность элювия. То есть, залегание нижней границы элювиальных грунтов обусловлено глубиной развития экзогенной трещиноватости в материнских породах.

Следовательно, в сложившихся геологических условиях формирование поверхности скольжения по подошве элювиальных грунтов, так же как и внутри их самих, исключается. Делювиальные грунты закономерно смещаются по кровле элювия под действием сил гравитации (что хорошо заметно на представленной фотографии - рис. 7). И именно эта граница рассматривается нами как поверхность скольжения потенциальных оползневых образований.

\section{Расчет коэффициентов устойчивости склонов}

Для расчета коэффициента устойчивости склона была использована формула Маслова по методике касательных сил для прислоненного откоса при отсутствии грунтовых вод (ноябрь-декабрь 2017 г.):

$$
K_{\mathrm{y}}=\frac{\sum\left(P_{i} \cos \alpha_{i} \operatorname{tg} \varphi_{i}+c_{i} l_{i}\right)}{\sum\left(P_{i} \sin \alpha_{i}+Q_{\mathrm{c}}\right)},
$$

где $P_{i}$ - полный вес одного из отсеков, на которые разбивается оползневой блок; $P_{i}=\gamma_{i} l_{i} h_{\mathrm{cp} . i} ; \gamma, \gamma_{i}-$ удельный вес грунта (индекс «i» обозначает номер рассматриваемого отсека); $l_{i}$ - длина подошвы или основания отсека (длина плоской поверхности скольжения); $h_{\text {ср. } i}$ - средняя толщина оползневого грунта в рассматриваемом отсеке; $\alpha_{i}$ - угол наклона подошвы отсека к горизонту (угол наклона плоской поверхности скольжения); $c_{i}, \varphi_{i}$ - удельное сцепление и угол внутреннего трения (параметры сопротивления сдвигу или сдвиговые характеристики) в уровне подошвы отсека (по поверхности скольжения в данном отсеке); $Q_{c i}-$ сейсмическая сила.

\section{СПИСОК ЛИТЕРАТУРЫ}

1. Дудлер И.В., Хайме Н.М., Лярский С.П. Методология инженерных изысканий для особо опасных, технически сложных и уникальных объектов // Геоэкология. Инженерная геология. Гидрогеология. Геокриология. - 2013. - № 2. - С. 115-129.

2. Конюшков В.В., Веселов А.А., Кондратьева Л.Н. Комплексный анализ результатов инженерных изысканий для проекти-

$$
Q_{\mathrm{c}}=\mu P,
$$

где $\mu$ - коэффициент динамической сейсмичности.

\section{Северный склон}

На участке обследования развития оползневых процессов наблюдаются выдержанные инженерногеологические условия: уклон поверхности склона имеет равномерное снижение - без резких перепадов высот, выделенные инженерно-геологические элементы также имеют выдержанную мощность и физико-механические характеристики в разрезе.

Поверхность скольжения определяется геологическим строением склона - делювиальные грунты сползают по коренным породам, представленным метаморфическими сланцами, кровля которых представляет собой слой элювиальных грунтов (ИГЭ-4).

В связи с такой выдержанностью условий не имеет смысла разбивать склон на отдельные призмы - он рассматривается как единый потенциально подвижный блок со следующими параметрами: $\gamma-2,2$ г $/ \mathrm{cm}^{3} ; h_{\text {ср }}-1,25 \mathrm{~m}$; ширина блока принята равной $1 \mathrm{~m} ; l_{i}-122,8 \mathrm{~m} ; \alpha_{i}-26,5^{\circ} ; c-0,015 \mathrm{MПа;}$ $\varphi-35^{\circ} ; \mu-0,05$ - для средних грунтовых сейсмических условий при сейсмичности 8 баллов.

В результате расчетов представленных значений по вышеуказанной формуле получили коэффициент устойчивости $\left(K_{\mathrm{y}}\right)$, равный 1,27 .

Склон устойчив.

Южный склон

$\gamma-2,2$ г $/ \mathrm{cm}^{3} ; h_{\text {ср }}-1,05 \mathrm{м}$; ширина блока принята равной $1 \mathrm{м} ; l_{i}-191,8 \mathrm{~m} ; \alpha_{i}-14,8^{\circ} ; c-0,015 \mathrm{MПа;}$ $\varphi-35^{\circ} ; \mu-0,05-$ для средних грунтовых сейсмических условий при сейсмичности 8 баллов. $K_{\mathrm{y}}=\mathbf{2 , 2 1 .}$ Склон устойчив.

\section{Западный склон}

$\gamma-2,2$ г $/ \mathrm{cm}^{3} ; h_{\text {ср }}-1,3 \mathrm{~m}$; ширина блока принята равной $1 \mathrm{м} ; l_{i}-188,68 \mathrm{м} ; \alpha_{i}-21,8^{\circ} ; c-0,015 \mathrm{MПа;}$ $\varphi-35^{\circ} ; \mu-0,05$ - для средних грунтовых сейсмических условий при сейсмичности 8 баллов. $K_{\mathrm{y}}=\mathbf{1 , 4 5}$. Склон устойчив.

\section{Заключение}

По результатам мониторинговых исследований развития склоновых процессов на объектах СТК «Горный воздух» - Северный склон, Южный и Западный склоны - выполнено уточнение инженерногеологических разрезов склонов и произведен расчет коэффициента устойчивости склонов по методике касательных сил для прислоненного откоса при отсутствии грунтовых вод - все склоны устойчивы.

рования, строительства и эксплуатации сооружений на территориях со склоновыми процессами // Известия Томского политехнического университета. Инжиниринг георесурсов. 2017. - T. 328. - № 11. - C. 111-125.

3. Landslide management in the UK - the problem of managing hazards in a «low-risk» environment / A.D. Gibson, M.G. Culshaw, C. Dashwood, C.V.L. Pennington // Landslides. - 2013. V. 10 (5). - P. 599-610. 
4. Крестин Б.М., Мальнева И.В. Активность оползневого и селевого процессов на территории Большого Сочи и ее изменения в начале XXI века // Геоэкология. Инженерная геология. Гидрогеология. Геокриология. - 2015. - № 1. - С. 58-66.

5. Осипов В.И., Мамаев А.А., Ястребов А.А. Оценка и ранжирование по степени оползневой опасности участков строительства олимпийских объектов в г. Сочи // Геоэкология. Инженерная геология. Гидрогеология. Геокриология. - 2013. № 6. - С. 530-537.

6. Семикина С.С., Сотников П.В. Оценка оползневой опасности береговых склонов на территории города Барнаул // Известия Томского политехнического университета. Инжиниринг георесурсов. - 2017. - Т. 328. - № 7. - С. 67-75.

7. Строкова Л.А., Ермолаева А.В. Природные особенности строительства участка газопровода «Сила Сибири» на участке Чаяндинское нефтегазоконденсатное месторождение - Ленск // Известия Томского политехнического университета. - 2015. T. 326. - № 4. - C. 41-55.

8. Castellanos B.A., Brandon T.L., VandenBerge D.R. Use of fully softened shear strength in slope stability analysis // Landslides. 2016. - V. 13 (4). - P. 697-709.

9. Chen D., Wei W., Chen L. Effects of terracing practices on water erosion control in China: a meta-analysis / / Earth-Science Review. 2017. - V. 173. - P.109-121.

10. Mulargia F., Visconti G., Geller R.J. Scientific principles and public policy // Earth-Science Review. - 2018. - V. 176. P. 214-221.

11. Roy S., Baruah A., Misra N.S. Mandal Effects of bedrock anisotropy on hillslope failure in the Darjeeling-Sikkim Himalaya: an insight from physical and numerical models // Landslides. 2015. - V. 12 (5). - P. 927-941.

12. Strokova L.A. Methods of estimating surface settlement during driving of urban tunnels // Soil Mechanics and Foundation Engineering. - 2010. - V. 47. - № 3. - P. 92-95.

13. Strokova L.A., Ermolaeva A.V., Golubeva V.V. The Investigation of Dangerous Geological Processes Resulting In Land Subsidence
While Designing the Main Gas Pipeline in South Yakutia // IOP Conference Series: Earth and Environmental Science. - 2016. № $43 .-6 \mathrm{p}$.

14. Geometrical characteristics of earthquake-induced landslides and correlations with control factors: a case study of the 2013 Minxian, Gansu, China, Mw 5.9 event / Y. Tian, C. Xu, J. Chen, Q. Zhou, L. Shen // Landslides. - 2017. - V. 14 (6). - P. 1915-1927.

15. Coupling fluvial processes and landslide distribution toward geomorphological hazard assessment: a case study in a transient landscape in Japan / C-Y. Tsou, M. Chigira, Y. Matsushi, N. Hiraishi, N. Arai // Landslides. - 2017. - V. 14 (6). - P. 1901-1914.

16. Walsby J.C. Geosure: a bridge between geology and decision making // Communicating Environmental Geoscience. - London, UK: Geological Society, 2008. - P. 81-87.

17. Научно-прикладной справочник по климату СССР. Серия 3. Многолетние данные. Ч. 1-6. Вып. 34. Сахалинская область. Л.: Гидрометеоиздат, 1990. - 483 с.

18. Геология СССР. Т. 33. Остров Сахалин. - М.: Недра, 1970. $431 \mathrm{c.}$

19. Гидрогеология CCCP. T. XXIV. Остров Сахалин. - М.: Недра, 1972. $-344 \mathrm{c}$.

20. Мелкий В.А., Осипенко А.Б., Ильин В.В. К вопросу о первичной природе метаморфических пород острова Сахалина // Тез. докл. конф. молодых ученых-вулканологов. - ПетропавловскКамчатский, 1985. - С. 23.

21. Левин Б.В., Ким Ч.У., Соловьев В.Н. Оценка сейсмической опасности и результаты детального сейсмического районирования для городов о. Сахалин // Тихоокеанская геология. 2012. - T. 31. - № 5. - C. 93-103.

22. Свод правил по инженерным изысканиям для строительства. СП-11-105-97. Ч.ІІІ. Правила производства работ в районах распространения специфических грунтов. - М.: Госстрой, 2004. -80 c.

Поступила 05.06.2018 2.

\section{Информация об авторах}

Ильин В.В., старший преподаватель кафедры строительства Технического нефтегазового института Сахалинского государственного университета.

Сахаров B.A., кандидат геолого-минералогических наук, заведующий лабораторией Сахалинского государственного университета. 


\title{
UDC 551.4.04
}

\section{CALCULATION OF STABILITY OF SLOPES IN THE AREAS OF CONSTRUCTION OF SPORTS AND TOURIST COMPLEX «GORNY VOZDUKH» (MOUNTAIN BOLSHEVIK, YUZHNO-SAKHALINSK)}

\author{
Vladimir V. llin',
}

vladimirilyin7@gmail.com

\author{
Valeriy A. Sakharov', \\ sakhsakh@yandex.ru \\ Sakhalin State University, \\ 290, Lenin street, Yuzhno-Sakhalinsk, 693000, Russia.
}

The relevance of the researches is caused by the need of safety ensuring in functioning of STK "Gorny vozdukh» objects. On sloping parts of the STK there is a danger of landslide processes. The first stage of specialized monitoring was performed to assess the dynamics of development of landslide processes in places of mass accumulation of people in the STK functioning.

The aim of the research is to study the dynamics of landslide processes and to assess the stability of slopes in places with a large number of holidaymakers and athletes for their safety.

Objects: Northern, Southern and Western slopes of Bolshevik mountain; soil composing the upper part of the lithosphere to a depth of 10 meters; groundwater.

Methods: relevant research in the cross stretch of the slope - route reconnaissance survey, excavation of test pits up to two meters deep (full passage deluvial sediments and the autopsy eluvial rocks), sampling of undisturbed structure with the interval of 0,2-0,3 m, geophysical investigation by ground penetrating radar scanning using a mobile GPR setup OKO-2, laboratory testing of selected soil samples. Groundwater is not detected within the research process.

Results. According to the research in November-December 2017 at three sites of STK "Gorny vozdukh» - the Northern, Southern and Western slopes - the authors have selected the representative sites on slopes, made specification of engineering-geological section of the listed slopes, in particular the position of the border "deluvium-eluvium», made the calculation of engineering-geological elements and the coefficients of stability of slopes within the studied plots according to the method of tangential forces for propped against the slope in the absence of groundwater.

\section{Key words:}

Slope, slope processes, landslide processes, deluvial deposits, eluvium, soil volumetric weight angle of internal friction, slope of sliding surface, groundwater, seismicity of the territory.

\section{REFERENCES}

1. Dudler I.V., Khayme N.M., Lyarskiy S.P. Metodologiya inzhenernykh izyskaniy dlya osobo opasnykh tekhnicheski slozhnykh i unikalnykh obyektov [Methodology of engineering surveys for especially dangerous, technically complex and unique objects]. Geoekologiya. Inzhenernaya geologiya. Gidrogeologiya. Geokriologiya, 2013, no. 2, pp. 115-129.

2. Konyushkov V.V., Veselov A.A., Kondratyeva L.N. Complex analysis of the results of engineering surveys for the design, construction and operation of structures in areas with slope processes. Bulletin of the Tomsk Polytechnic University. Geo Assets Engineering, 2017, vol. 328, no. 11, pp. 111-125. In Rus.

3. Gibson A.D., Culshaw M.G., Dashwood C., Pennington C.V.L. Landslide management in the UK - the problem of managing hazards in a «low-risk» environment. Landslides, 2013, vol. 10 (5), pp. $599-610$

4. Krestin B.M., Malneva I.V. Activity of landslide and mudflow processes in the territory of Greater Sochi and its changes at the beginning of the XXI century. Geoecology. Engineering geology. Hydrogeology. Geocryology, 2015, no. 1, pp. 58-66. In Rus.

5. Osipov V.I., Mamaev A.A., Yastrebov A.A. Assessment and ranking by the degree of landslide hazard of sites for construction of Olympic facilities in the city of Sochi. Geoecology. Engineering geology. Hydrogeology. Geocryology, 2013, vol. 6, pp. 530-537. In Rus.

6. Semikina S.S., Sotnikov P.V. Assessment of landslide hazard of the coastal slopes in the city of Barnaul. Bulletin of the Tomsk Polytechnic University. Geo Assets Engineering, 2017, vol. 328, no. 7, pp. 67-75. In Rus.

7. Strokova L.A., Ermolaeva A.V. Natural features of construction of the main gas pipeline «The Power of Siberia» on a site Chayan- dinskoe oil and gas field - Lensk. Bulletin of the Tomsk Polytechnic University, 2015, vol. 326, no. 4, pp. 41-55. In Rus.

8. Castellanos B.A., Brandon T.L., Vanden Berge D.R. Use of fully softened shear strength in slope stability analysis. Landslides, 2016, vol. 13 (4), pp. 697-709.

9. Chen D., Wei W., Chen L. Effects of terracing practices on water erosion control in China: a meta-analysis. Earth-Science Review, 2017, vol. 173, pp. 109-121.

10. Mulargia F., Visconti G., Geller R.J. Scientific principles and public policy. Earth-Science Review, 2018, vol. 176, pp. 214-221.

11. Roy S., Baruah A., Misra S., Mandal N. Effects of bedrock anisotropy on hillslope failure in the Darjeeling-Sikkim Himalaya: an insight from physical and numerical models. Landslides, 2015, vol. 12 (5), pp. 927-941

12. Strokova L.A. Methods of estimating surface settlement during driving of urban tunnels. Soil Mechanics and Foundation Engineering, 2010, vol. 47, no. 3, pp. 92-95.

13. Strokova L.A., Ermolaeva A.V., Golubeva V.V. The Investigation of Dangerous Geological Processes Resulting In Land Subsidence While Designing the Main Gas Pipeline in South Yakutia. IOP Conference Series: Earth and Environmental Science, 2016, no. $43,6 \mathrm{p}$.

14. Tian Y., Xu C., Chen J., Zhou Q., Shen L. Geometrical characteristics of earthquake-induced landslides and correlations with control factors: a case study of the 2013 Minxian, Gansu, China, Mw 5.9 event. Landslides, 2017, vol. 14 (6), pp. 1915-1927.

15. Tsou C-Y., Chigira M., Matsushi Y., Hiraishi N., Arai N. Coupling fluvial processes and landslide distribution toward geomorphological hazard assessment: a case study in a transient landscape in Japan. Landslides, 2017, vol. 14 (6), pp. 1901-1914. 
16. Walsby J.C. Geosure: a bridge between geology and decision making. Communicating Environmental Geoscience. London, UK, Geological Society, 2008. pp. 81-87.

17. Nauchno-prikladnoy spravochnik po klimatu SSSR. Seriya 3. Mnogoletnie dannye. Ch. 1-6. Vyp. 34. Sakhalinskaya oblast [Scientific and Applied Handbook on the Climate of the USSR. Series 3. Perennial data. P. 1-6. Iss. 34. The Sakhalin area]. Leningrad, Gidrometeoizdat Publ., 1990. 483 p.

18. Geologiya SSSR. T. 33. Ostrov Sakhalin [Geology of the USSR. Vol. 33. Sakhalin Island]. Moscow, Nedra Publ., 1970. 431 p.

19. Gidrogeologiya SSSR. T. XXIV. Ostrov Sakhalin [Hydrogeology of the USSR. Vol. XXIV. Sakhalin Island]. Moscow, Nedra Publ., 1972. No. 2, $344 \mathrm{p}$.

20. Melkiy V.A., Osipenko A.B., Ilin V.V. K voprosu o pervichnoy prirode metamorficheskikh porod ostrova Sakhalina [To the issue

\section{Information aboit the authors}

Vladimir V. Ilin, senior teacher, Sakhalin State University.

Valeriy A. Sakharov, Cand. Sc., head of the laboratory, Sakhalin State University. of the primary nature of the metamorphic rocks of the Sakhalin Island]. Tezisy dokladov konferentsii molodykh uchenykh-vulkanologov [Proc. of the Conference of young scientists-volcanologists]. Petropavlovsk-Kamchatsky, 1985. p. 23.

21. Levin B.V., Kim Ch.U., Solovyev V.N. Seismic hazard assessment and results of detailed seismic zoning for cities is. Sakhalin. Pacific Geology, 2012, vol. 31, no. 5, pp. 93-103. In Rus.

22. Svod pravil po inzhenernym izyskaniyam dlya stroitelstva. SP-11-105-97. Ch. III. Pravila proizvodstva rabot v rayonakh rasprostraneniya spetsificheskikh gruntov [Code of rules for engineering surveys for construction. SP-11-105-97. P. III. Rules for works in areas of distribution of specific soils]. Moscow, Gosstroy Publ., 2004. 80 p.

Received: 5 June 2018. 